\title{
MERCURY IN THE SANTA CRUZ CHANNEL, NE BRAZIL - A POTENTIAL RISK
}

\author{
Ute MEYER ${ }^{1}$; Carmen MEDEIROS ${ }^{2 *}$
}

\author{
${ }^{1}$ Center for Tropical Marine Ecology, Bremen, Germany. E-mail: UteM@aol.com \\ 2Departamento de Oceanografia, Universidade Federal de Pernambuco, Recife/PE, Brasil. \\ E-mail: cmlimongi@gmail.com \\ *Autor correspondente
}

\begin{abstract}
RESUMO. O nível de contaminação por Mercúrio no Canal de Santa Cruz foi avaliado cerca de dois anos após cessado os lançamentos de efluentes contaminados por $\mathrm{Hg}$ em seu principal afluente (Rio Botafogo) bem como o papel dos sedimentos de mangue como sumidouros ou fontes secundárias de $\mathrm{Hg}$ dentro do sistema e/ou para áreas costeiras adjacentes. Ostras-de-mangue, material em suspensão e sedimentos representativos dos diferentes compartimentos do Canal, períodos sazonais e estágios de maré foram analizados. As concentrações de $\mathrm{Hg}$ em ostras foi de 0,27-2,21 ppm (MS massa seca); de 0,04-6,20 ppm em sedimento total (MS), de 0,3-0,5 ppm na fração <63 $\mu \mathrm{m}$ e de 0,43-5,56 ppm (MS) no material em suspemsão, correspondendo a 4-175 $\mathrm{ngL}^{-1}$ de $\mathrm{Hg}$ particulado. Os resultados corroboram a importância da matéria fina rica em orgânicos na acumulação de $\mathrm{Hg}$, mas indicam que a longo-prazo, os sedimentos de mangue não funcionam como armadilha para o $\mathrm{Hg}$, que é remobilizado, presumivelmente como espécies biodisponíveis. A baixa exportação de $\mathrm{Hg}$ para áreas costeiras sugere que muito do $\mathrm{Hg}$ remobilizado cicla no sistema ou é liberado para a atmosfera. Ambos os processos representam risco consideráveis para os organismos aquáticos e para os seres humanos expostos ao mercúrio.
\end{abstract}

Palavras-Chave: mercúrio, manguezal, estuário, sedimento, ostra-de-mangue.

\begin{abstract}
This work evaluated the level of mercury contamination in a mangrove system (Santa Cruz Channel) a couple of years after $\mathrm{Hg}$ discharge into its main tributary (Botafogo River) ceased, as well as the role of mangrove sediments as sinks or secondary sources of mercury whiting the system and/or to coastal areas. Mangrove oysters, suspended matter and sediment cores representing different compartments of the Channel and seasonal and tidal stages were analyzed. Mercury concentrations was 0.27-2.21 ppm (dry mass DM) in mangrove oysters; 0.04-6.20 ppm in total sediment (DM) and 0.3-20.5 $\mathrm{ppm}$ in relation to the grain size fraction $<63 \mu \mathrm{m}$. Mercury concentrations in suspended matter were between 0.43-5.56 ppm (DM), corresponding to 4-175 ngL-1 particulate mercury. Results corroborates the importance of fine and organic-rich matter for the accumulation of mercury but also indicated that mangrove sediments do not function as a long-term trap for $\mathrm{Hg}$. Instead, mercury is remobilized from the sediments, presumably as bioavailable species. As the export to coastal areas is small, a large portion of the remobilized $\mathrm{Hg}$ probably cycles within the system or is released into the air. Both processes represent a considerable risk for aquatic organisms and humans exposed to the mercury.
\end{abstract}

Keywords: mercury, mangrove, estuary, sediment, mangrove-oyster.

\section{INTRODUCTION}

Vast mangrove areas have been destroyed due to urban and industrial growth (Lacerda, 1993) and are threatened by industrial and municipal sewage discharge (Brown, 1988; Gomez, 1988). Environmental research on the pollution of mangrove areas has concentrated on the fate of heavy metals in the system (e.g. Barcellos et al., 1991; Harbison, 1986; Lacerda et al., 1991; Mackey et al., 1992; Maddock and Motta, 1982; Pfeiffer et al., 1988; Queiroz et al., 
1993; Silva et al., 1990;). The investigations have focused on the level of heavy metal pollution and the behavior of metals in mangrove areas. The crucial question is to what degree a mangrove area functions as a "sink" for metals (accumulation within the system) or as a secondary "source" of metals (remobilization and export to the ocean).

The fate of heavy metals in estuaries mainly depends on the availability of solid surfaces and on the metal species in the aquatic system. The various species of a metal are defined as "the individual physico-chemical forms of the element, which together make up its total concentration" (Florence, 1982). Such metal species are for instance dissolved species (free or complexed ions) or particulate species adsorbed on organic matter or clay. Factors influencing the speciation of metals are for instance $\mathrm{pH}$, redox potential, presence of complexing agents, salinity, composition of the particulate matter, competition with other elements for surface sites. In estuarine ecosystems these influences are particularly complex and can vary strongly with the tides. Hence, adsorbed metals can be remobilized into the water column and become bioavailable (Salomons and Förstner, 1984).

Mercury may occur in various species such as elementary form or bound in compounds. It is a toxic heavy metal that affects particularly the central nervous system and the brain functions of vertebrates (Müller et al., 1991) and influences other physiological and biochemical processes such as embryonic development and growth in aquatic organisms (e.g. Brock, 1992; GESAMP, 1988; Khan and Weis, 1987; Martin et al., 1981; Nascimento, 1982). Mercury may occur in numerous species as metallic mercury in vapor or liquid form, inorganic mercury ions $\left(\mathrm{Hg}^{2+}, \mathrm{Hg}^{+}\right)$with its compounds, and organically bound mercury (e.g. methylmercury, ethylmercury, phenylmercury) (von Burg and Greenwood, 1991). Mercury can be converted from one species to another by physico-chemical processes and by bacterial activity (Jensen and Jernelöv, 1972). These transformation processes depend for instance on oxygen supply (Jensen and Jernelöv, 1972), salinity (Blum and Bartha, 1980; Compeau and Bartha, 1983), temperature (Wright and Hamilton 1982), pH (Ramlal et al., 1985), organic carbon (Miskimmin, 1991), mercury concentration (Wright and Hamilton, 1982), and determine the bioavailability of mercury for aquatic organisms. Due to mercury losses from industrial processes, elevated mercury concentrations have been detected in many estuarine and marine areas (reviewed in e.g. Bernhard, 1988; GESAMP 1988). Mercury accumulation in the marine environment first gained international attention, after enormous amounts of mercury had been released by adjacent industries into Minamata Bay, Japan, which caused dramatic poisoning of the local population (Kudo and Miyahara, 1988).

A chlor-alkali plant located at the Botafogo River that have being producing, caustic soda by the amalgamation process since 1963, was responsible for high mercury contaminations in the sediments, fish and shellfish in the Santa Cruz Channel system (CETESB, 1981; 1984). Emissions have decreased considerably since the construction of a precipitation basin by the plant in 1986, but further emissions occurred until 1991 due to technical failure (CAI Histórico, 
CPRH unpublished data). This study aimed to characterize the level of mercury pollution in the Santa Cruz Channel two-three years after $\mathrm{Hg}$ discharges ceased and intended to help elucidate the role of mangroves for the fate of mercury in that channel. The spatial distribution patterns of mercury in different compartments of the system, the seasonal changes as well as tidal cycles at the exits of the channel were studied in order to assess the environmental factors affecting remobilization, transport and bioavailability of mercury.

\section{MATERIAL AND METHODS}

Collections were done from July to September 1993, from April to June 1994 and from late November to December 1994. Samples of the mangrove oyster Crassostrea rhizophorae (Guilding 1828) with shell length of $40-60 \mathrm{~mm}$, surface sediments of the intertidal areas, and water samples (filtered through pre-weighed $0.4 \mu \mathrm{m}$ polycarbonate filters) were collected at different stations in the channel and the Botafogo River (Fig. 1). One control station was located in an uncontaminated mangrove area at the Goiana River (GOI) about $30 \mathrm{~km}$ north of Itamaracá. The samples (oyster tissue, sediments, and filters with suspended matter) were freeze-dried and homogenized. Subsamples of the original sediments were used for grain size determinations (wet sieving in a 63- $\mu \mathrm{m}$ mesh sieve, Loring and Rantala, 1992). Total organic matter was determined by mass loss of the dried sediment after ignition at $500^{\circ} \mathrm{C}$ for $24 \mathrm{~h}$ (Langston, 1982).

\section{DISTRIBUTION PATTERNS OF MERCURY IN SEDIMENT TRANSECTS}

Six transects (A-F) of sediment cores were performed between October 1993 and December 1994, with an additional transect in 1991 (G). Sampling sites for the transects were selected according to different topographical criteria such as current velocity, depth and sediment structure, and based on mercury analyses of surface sediments collected in 1993 (Fig. 1). Between 3 and 24 sediment cores were taken from shore to shore at the selected sampling sites (Fig. 2). Sediment profiles were sampled with plastic-tubes ( 1 inch $=25.4 \mathrm{~mm}$ inner diameter and $0.6 \mathrm{~m}$ length). From the upper end of the core one $30 \mathrm{~mm}$-layer was sliced off, which comprised the oxidized top layer of the sediment. Subsequently, $100 \mathrm{~mm}$-slices were sampled towards the lower end of the core. All sediment samples were stored at $-20^{\circ} \mathrm{C}$ until further processing.

\section{MERCURY TRANSPORTED WITH SUSPENDED MATTER DURING TIDAL CYCLES}

Suspended matter was sampled during two tidal cycles (rainy and dry seasons, 1994) at the North (I) and South (II) exits of the channel (Fig. 1). Samples were taken at different spots ("sampling points", Fig. 3) of the cross-section and at different tidal stages: ebb, low tide, flood and high tide. 


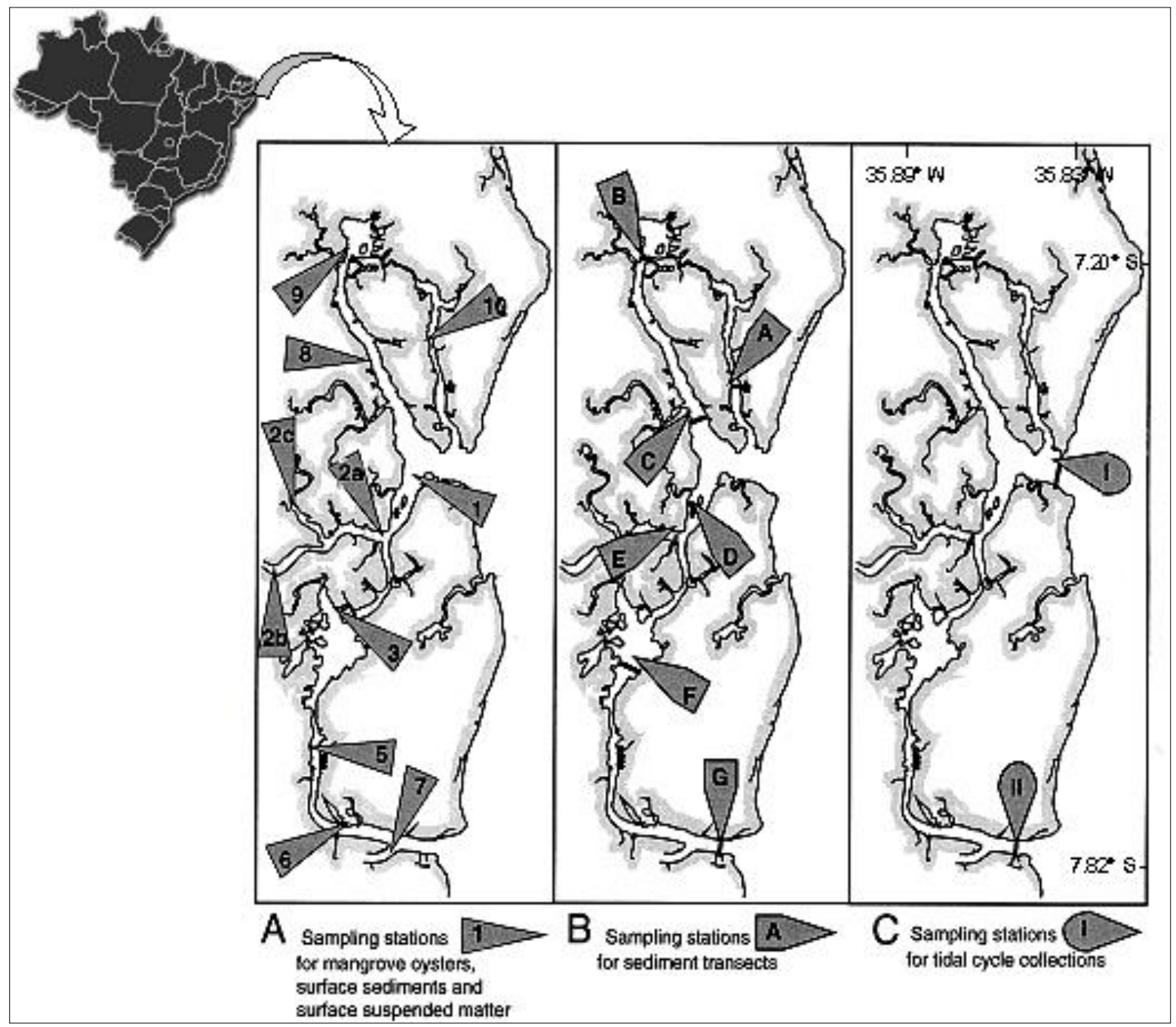

Figure 1. Map of sampling sites in the Santa Cruz Channel.

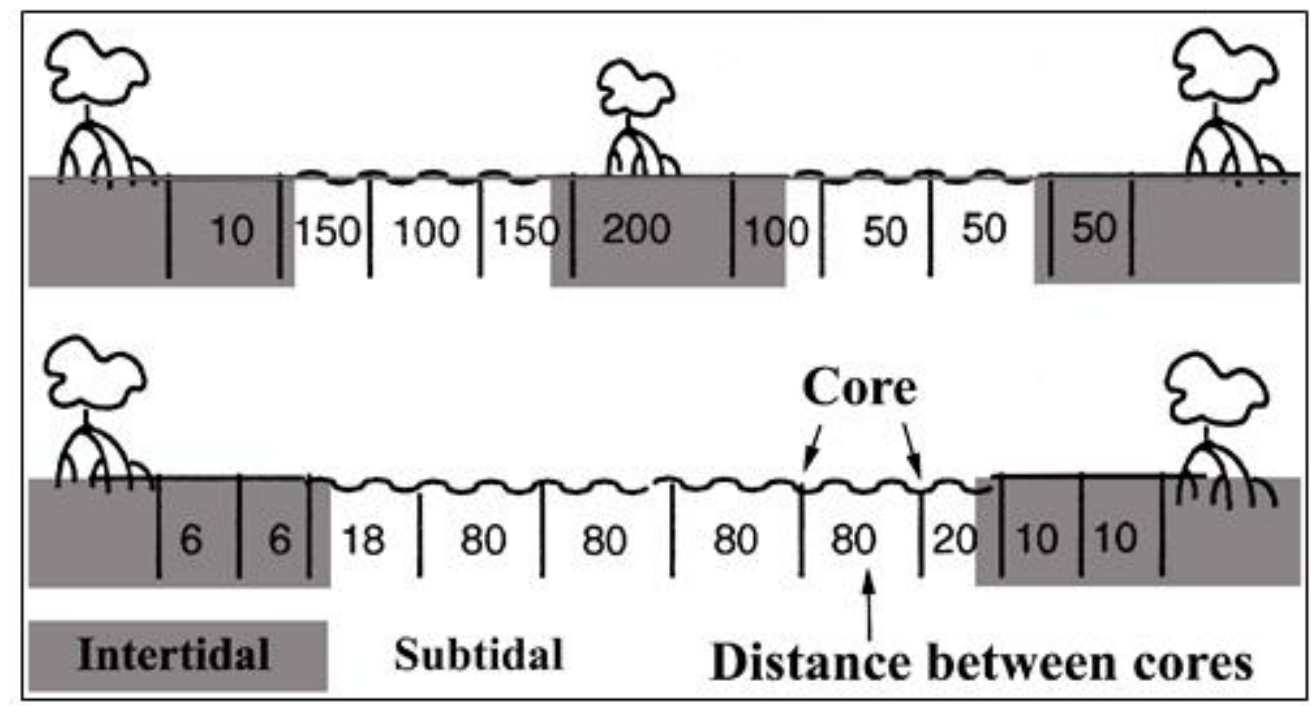

Figure 2. Scheme of sediment transects from shore to shore. 
Sampling points within the cross-sections were located at specific depths and distances from the shores depending on the width of the cross-section. Water samples were taken with a Nansen bottle. A mass balance of the mercury transport during these tidal cycles was calculated by the area-velocity method suggested by Woodroffe (1985). From the bathymetries and the water level data, the areas of transects were reconstructed for the different stages of the tide. The area of the transect during a tidal state was divided into subareas, corresponding to the amount of sampling points. From the mercury and suspended matter concentrations and the current velocity the import or export of mercury per subarea and time of the tide was calculated and summed up for the whole transect. The balance over four tidal states measured was used as a rough approximation of the transport during a tidal cycle.

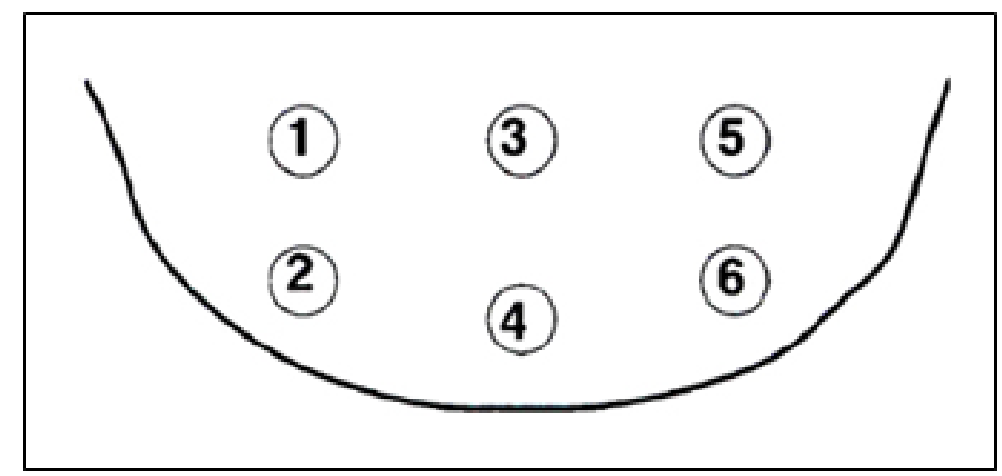

Figure 3. Scheme of the sampling points in a transect.

\section{PHYSICO-CHEMICAL PARAMETERS}

Surface temperature, salinity and $\mathrm{pH}$ were measured with hand-held probes at $0.5 \mathrm{~m}$ depth, at about the same time, when oysters and surface suspended matter were sampled. During the tidal cycles temperature, salinity and $\mathrm{pH}$ were measured either in subsamples from the Nansen bottle using the hand probes or with a CTD probe. Current measurements (speed and direction) were carried out using a submerged drag as a current vane (Kjerfve and Medeiros, 1989).

\section{MERCURY DETERMINATION}

Mercury determination was done by cold-vapor-generation (Hatch and Ott, 1968) after digestion of samples in $2 \mathrm{ml}$ nitric acid (suprapur) under pressure for four hours at $140^{\circ} \mathrm{C}$. Mercury concentrations always refer to the dry mass of a sample (dry oyster tissue, dry sediment, dry suspended matter). Unless otherwise stated, the mercury concentrations in sediments are reported as the concentrations in the total fraction. Statistical analyses were 
conducted by analysis of variance (ANOVA). Results were reported using a significance level of $95 \%(p<0.05)$. A detailed description of the methods is given in Meyer (1996).

\section{RESULTS}

\section{SPATIAL AND SEASONAL DISTRIBUTION OF MERCURY IN THE SANTA CRUZ CHANNEL}

The distribution of mercury in mangrove oysters, surface sediments and surface suspended matter in the Santa Cruz Channel varied between stations and seasons. Spatial differences were pronounced and showed a similar distribution pattern in all compartments investigated (Fig. 4).

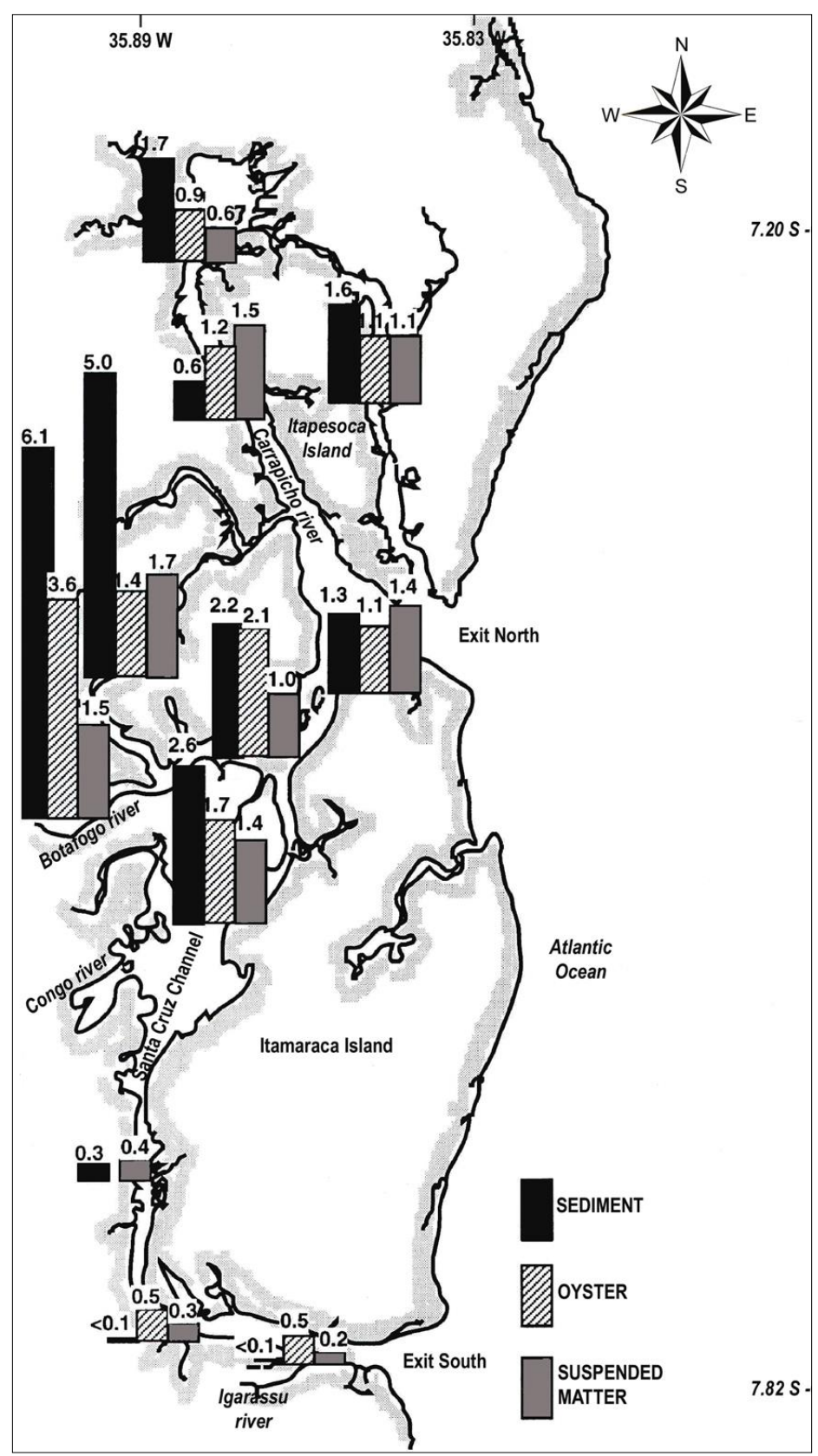


Figure 4. Distribution pattern of mercury concentrations in mangrove oysters, total sediments and suspended matter from July 1993.

During the three seasons, highest mercury concentrations in the oysters, suspended matter, total sediment and fine sediment fraction were always measured at the Botafogo River Sts. $2 b$ or $2 c$. The lowest values were determined at the southernmost Sts. 5-7 and mercury concentrations also decreased towards the northernmost St. 9. Only small differences were found between the inner Sts. 1, 2a, 3 and 8 . The seasonal variations of mercury concentrations in the Santa Cruz Channel did not exhibit a distinct pattern.

Average mercury concentrations in oysters ranged from 0.29 to $2.21 \mathrm{ppm}$ in the rainy season $1994,0.27$ to $1.75 \mathrm{ppm}$ in the dry season 1994 and $0.30-1.70 \mathrm{ppm}$ in the rainy season 1993. The oysters of the control station showed mercury values below the minimum level in the study area (0.13 ppm as compared to $0.29 \mathrm{ppm}$ at St. 6$)$.

Mercury concentrations in the surface sediments (total fraction) were $0.04-6.20 \mathrm{ppm}$ in the rainy season $1993,0.21$ to $5.11 \mathrm{ppm}$ in the rainy season 1994 and 0.09 to $5.18 \mathrm{ppm}$ in the dry season 1994. Total organic matter varied strongly between 3\%-27\% within the study area, but no seasonal pattern emerged. At the control station, the mercury concentrations in the total fraction and in the $<63 \mu \mathrm{m}$ fraction were below the lowest concentrations in the channel (total: $0.07 \mathrm{ppm}$ versus $0.21 \mathrm{ppm},<63 \mu \mathrm{m}: 0.18 \mathrm{ppm}$ versus $0.56 \mathrm{ppm}$ ).

Concentrations of mercury in suspended matter, of suspended matter and of particulate mercury showed high variations, but trends were clearly discernible. For each season, spatial differences were significant and levels generally increased towards the Botafogo River stations, except for the more evenly distributed suspended matter concentrations during the rainy season 1993 and the dry season 1994. The seasonal differences of mercury concentrations in suspended matter were low with averages between 0.47-3.62 ppm in the rainy season 1993, 0.54-4.41 ppm in the rainy season 1994 and 0.43-4.56 ppm in the dry season 1994. The seasonal variations of suspended matter concentrations were more pronounced, with lowest values in the dry season 1994 (6.8-20.1 $\left.\mathrm{mg} \mathrm{L}^{-1}\right)$ and highest values in the rainy season 1994 (6.2-94.7 $\left.\mathrm{mg} \mathrm{L}^{-1}\right)$. The distribution of particulate mercury concentrations generally followed a similar pattern as the mercury concentrations.

\section{SEDIMENT TRANSECTS}

The sediment core transects in the Santa Cruz Channel revealed major differences between the intertidal and subtidal zones. According to these differences, the transects can be divided in two groups (Fig. 5).

In the first group total mercury concentrations were clearly higher in the intertidal zones of the northern and southern parts of the channel at transect $A, B, C, D$ and $G$, corresponding with higher portions of fine sediments and of organic matter. However, the mercury 
concentrations in the fine grain size fraction were more evenly distributed without significant differences between the subtidal and intertidal zones.

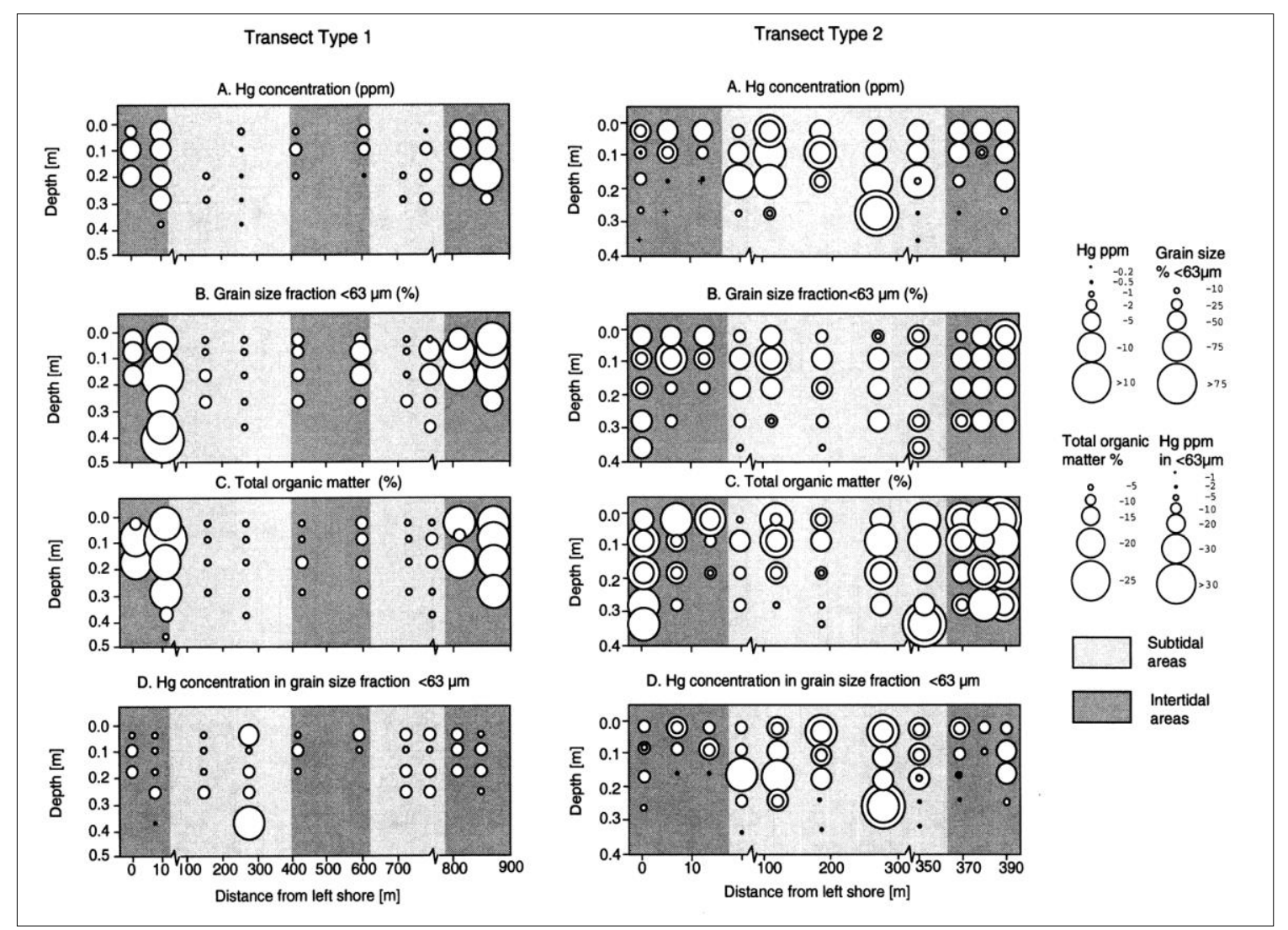

Figure 5. Sediment core data from transect type 1 and 2 (results of two parallel samples are presented as two nested circles, if these samples belong to different size classes). The figures present schematic lateral views on the transects from shore to shore. Circle size indicates: $(A)$ mercury concentration (ppm); $(B)$ percentage of grain size-fraction $<63 \mu \mathrm{m}$; (C) percentage of total organic matter; and (D) calculated mercury concentration in the grain size-fraction $<63 \mu \mathrm{m}$. Dark shaded areas depict intertidal nearshore zones; light shaded areas depict subtidal zones.

Mercury concentrations in total sediment correlated significantly with grain size at these transects, except for the southern transect G (Exit South). Total mercury correlated with total organic matter in the Carrapicho River (transect $C$ ) and at the Mangrove Island transect D.

In contrast, the second group (transect $E$ and F, Congo River), which comprised the inner transects, showed significantly higher mercury concentrations in the subtidal zones (Fig. 5). In these regions, the fine sediment and the organic matter were more evenly distributed. Highest levels of total mercury concentrations and total organic matter were found at these two transects. The differences between mercury concentrations in the intertidal zones and the subtidal zone were significant. No significant differences existed between sub- and intertidal zones in the distribution of grain size and total organic matter. The mercury concentrations in 
the grain size fraction $<63 \mu \mathrm{m}$ corroborated the distribution pattern of mercury concentrations in the total sediment fraction with significantly higher values in the subtidal zone.

\section{TIDAL CYCLES}

The results of the tidal cycle collections are presented for five locations in Table 1. Mercury concentration in suspended matter, concentration of suspended matter per liter, concentration of particulate mercury per liter, salinity, $\mathrm{pH}$, temperature and current velocity are given as average values of the samples from one complete transect during one tidal stage. The sampling time is given as the mid-value from the start to the end of one complete transect. Thus, standard deviations are shown for the values measured and for the sampling time. Physicochemical parameters (salinity, $\mathrm{pH}$ and temperature) were uniform over the whole profile indicating a well-mixed water column. Salinity changes corresponded to the tides with highest values during high tide and lowest values during low tide. $\mathrm{pH}$ variations were extremely low (except for a bit stronger changes in the Botafogo River), usually with slightly lower values before and during low tide at the inner stations. At the exits of the channel, this pattern was not always discernible.

At the Exit North mercury and suspended matter concentrations (A-C) were higher in the rainy season (May 1994) than in the dry season (December 1994). Salinity and pH were slightly higher in the dry season. In the rainy season highest values and the most pronounced

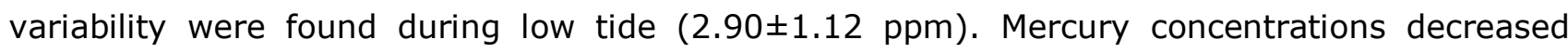
significantly towards high tide $(1.27 \pm 0.49 \mathrm{ppm})$ and reached the same levels as three hours before low tide $(1.22 \pm 0.43 \mathrm{ppm})$. Suspended matter concentrations were low. The differences were not significant due to high variabilities.

Table 1. Tidal cycle collections of suspended matter at the exits of the Santa Cruz Channel. The transect data ( $\mathrm{nd}=$ not determined) at each tidal stage are presented as mean \pm standard deviations $(n=6-8)$.

\begin{tabular}{|c|c|c|c|c|c|c|c|c|c|}
\hline $\begin{array}{l}\text { Exit / } \\
\text { Season }\end{array}$ & $\begin{array}{l}\text { Tidal } \\
\text { Stage }\end{array}$ & $\begin{array}{c}\text { Sampling } \\
\text { Time }\end{array}$ & $\begin{array}{c}\text { Hg } \\
(p p m \text { DM) }\end{array}$ & $\begin{array}{c}S M \\
\left(\mathrm{mg} \mathrm{L}^{-1}\right)\end{array}$ & $\begin{array}{l}\text { Part. Hg } \\
\left(\text { ng L }^{-1}\right)\end{array}$ & Salinity & pH & $\begin{array}{l}\text { Temp. } \\
\left({ }^{\circ} \mathrm{C}\right)\end{array}$ & $\begin{array}{l}\text { Current } \\
\left(\mathrm{m} \mathrm{s}^{-1}\right)\end{array}$ \\
\hline \multirow{8}{*}{ 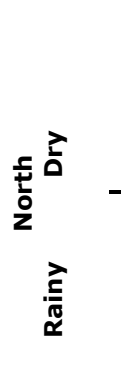 } & Ebb & $07: 12 \pm 00: 08$ & $1.22 \pm 0.43$ & $10.9 \pm 3.5$ & $12.4 \pm 3.4$ & $32.8 \pm 0.5$ & $7.8 \pm 0.1$ & nd & $-0.36 \pm 0.05$ \\
\hline & Low & $10: 13 \pm 00: 10$ & $2.90 \pm 1.12$ & $9.3 \pm 4.7$ & $25.1 \pm 13.6$ & $26.7 \pm 0.6$ & $7.8 \pm 0.0$ & nd & $-0.25 \pm 0.05$ \\
\hline & Flood & $13: 22 \pm 00: 09$ & $2.02 \pm 0.50$ & $15.8 \pm 8.0$ & $34.0 \pm 21.2$ & $29.6 \pm 0.4$ & $7.6 \pm 0.1$ & nd & $0.18 \pm 0.06$ \\
\hline & High & $16: 07 \pm 00: 08$ & $1.27 \pm 0.49$ & $9.6 \pm 3.0$ & $11.8 \pm 3.7$ & $33.7 \pm 0.9$ & $7.8 \pm 0.1$ & nd & $0.28 \pm 0.08$ \\
\hline & Ebb & $17: 48 \pm 00: 43$ & $1.43 \pm 0.37$ & $8.0 \pm 0.9$ & $14.8 \pm 8.4$ & $35.6 \pm 0.6$ & $8.3 \pm 0.1$ & $29.3 \pm 0.1$ & $-0.45 \pm 0.19$ \\
\hline & Low & $20: 58 \pm 00: 43$ & $1.72 \pm 0.58$ & $8.4 \pm 3.9$ & $16.3 \pm 11.6$ & $33.7 \pm 0.1$ & $8.1 \pm 0.0$ & $28.9 \pm 0.1$ & $-0.04 \pm 0.23$ \\
\hline & Flood & $00: 30 \pm 11: 25$ & $1.25 \pm 0.70$ & $8.6 \pm 3.5$ & $11.5 \pm 8.7$ & $35.0 \pm 1.0$ & $8.2 \pm 0.1$ & $28.6 \pm 0.2$ & $0.37 \pm 0.09$ \\
\hline & High & $03: 24 \pm 00: 55$ & $1.21 \pm 0.28$ & $4.7 \pm 0.7$ & $5.8 \pm 1.9$ & $36.4 \pm 0.1$ & $8.3 \pm 0.0$ & $28.5 \pm 0.2$ & $0.10 \pm 0.33$ \\
\hline \multirow{5}{*}{ 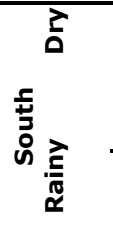 } & $\mathrm{Ebb}$ & $07: 40 \pm 00: 42$ & $0.37 \pm 0.13$ & $17.3 \pm 6.7$ & $6.6 \pm 4.4$ & $27.6 \pm 1.5$ & $7.9 \pm 0.1$ & $27.7 \pm 0.3$ & nd \\
\hline & Low & $10: 03 \pm 00: 41$ & $0.53 \pm 0.10$ & $9.4 \pm 2.6$ & $4.9 \pm 1.5$ & $23.1 \pm 1.0$ & $7.7 \pm 0.0$ & $27.8 \pm 0.1$ & nd \\
\hline & Flood & $12: 52 \pm 00: 58$ & $0.53 \pm 0.36$ & $14.5 \pm 3.8$ & $8.2 \pm 5.7$ & $24.1 \pm 0.6$ & $7.6 \pm 0.1$ & $27.9 \pm 0.3$ & nd \\
\hline & Ebb & $10: 30 \pm 00: 31$ & $0.59 \pm 0.20$ & $10.9 \pm 4.3$ & $6.7 \pm 3.9$ & $34.0 \pm 0.1$ & $8.0 \pm 0.0$ & $29.5 \pm 0.1$ & $-0.11 \pm 0.27$ \\
\hline & Low & $13: 30 \pm 00: 27$ & $0.40 \pm 0.09$ & $14.1 \pm 2.7$ & $5.7 \pm 2.1$ & $34.9 \pm 0.2$ & $8.1 \pm 0.0$ & $29.7 \pm 0.1$ & $0.32 \pm 0.09$ \\
\hline
\end{tabular}




\begin{tabular}{cccccccccc} 
Flood & $16: 33 \pm 00: 29$ & $0.39 \pm 0.20$ & $6.2 \pm 0.8$ & $2.5 \pm 1.8$ & $36.6 \pm 0.2$ & $8.4 \pm 0.0$ & $29.9 \pm 0.3$ & $0.36 \pm 0.23$ \\
High & $19: 38 \pm 00: 29$ & $0.32 \pm 0.08$ & $9.0 \pm 3.2$ & $2.7 \pm 0.8$ & $35.9 \pm 0.5$ & $8.3 \pm 0.1$ & $29.9 \pm 0.1$ & $-0.65 \pm 0.10$ \\
\hline
\end{tabular}

The variabilities in mercury and suspended matter concentrations were higher during the dry season, due to delays during sampling. Mercury concentrations (0.12-2.57 ppm) showed higher values before and during low tide. Suspended matter reached lowest concentrations during high tide. Particulate mercury concentrations (1-36 $\left.\mathrm{ngL}^{-1}\right)$ showed highest values before and during low tide. The variations in the average mercury concentration in suspended matter as well as the mercury concentrations per liter showed higher variations during a tidal cycle than between the two tidal cycles. A low mercury export of $0.8 \mathrm{mg} \mathrm{s}^{-1}$ could be detected in the rainy season and a higher export of $4.9 \mathrm{mg} \mathrm{s}^{-1}$ in the dry season (Fig. 6). An annual calculation yields an export of 0.03-0.15 $\mathrm{t}$ of mercury through the Exit North.

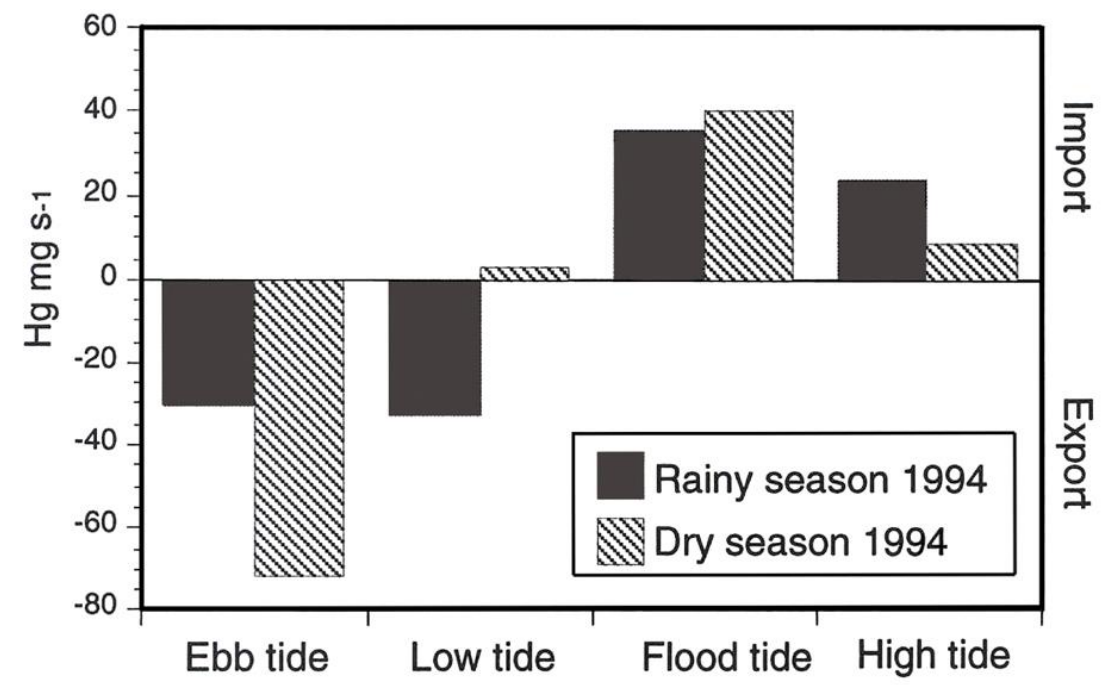

Figure 6. Transport of particulate mercury through the Exit North during different tidal stages. Positive values indicate import, negative values export. Dark shaded boxes depict collections during the rainy season 1994, hatched boxes depict collections during the dry season 1994.

For the Exit South, high tide values are not available for May 1994. Variations in mercury and suspended matter concentrations were low, but significant. Mercury reached lowest concentrations before low tide, when suspended matter concentrations peaked. Particulate mercury showed lowest values during low tide. In December, all values were slightly higher before and during low tide. Mercury concentrations in the suspended matter were too low to calculate a reliable balance. Obviously, the export rate at the Exit South is very low as compared to the Exit North.

\section{DISCUSSION}

Elevated mercury concentrations in the mangrove oysters from the Santa Cruz Channel were restricted to the Botafogo River and the northern part of the channel. Regarding the 
mercury limit for fish and shellfish recommended by the Who (1976), the concentrations (calculated on a wet mass basis WM) did not exceed the WHO limit of $0.5 \mathrm{ppm}$ WM. The maximum value found in mangrove oysters was $0.40 \mathrm{ppm}$ WM.

The mercury concentrations of the mangrove oysters from Santa Cruz Channel were much higher than of those from the uncontaminated Goiana station; even the lowest average concentrations in the southern part of the channel exceeded the Goiana station values. There was an eight-fold increase in the average mercury concentrations of oysters from the least (0.2$0.3 \mathrm{ppm} \mathrm{DM})$ to the most contaminated stations (1.8-2.2 ppm DM) in the channel. The PTWI (provisional tolerable weekly intake, Who 1976) of $0.3 \mathrm{mg}$ mercury is exceeded, if $1.5-3.0 \mathrm{~kg}$ WM of mangrove oysters from the northern stations are consumed, or fish and shellfish containing similar mercury concentrations. A kilogram of fish per individual seems to be a reasonable minimum estimate of the weekly amount consumed by the fishermen and their families. However, mercury concentrations measured in two common clupeid fish species from Santa Cruz Channel were low (Meyer and Börner unpubl.).

The spatial distribution patterns of mercury in the Santa Cruz Channel clearly pointed to the Botafogo River as the origin of the mercury. Generally, the highest concentrations in mangrove oysters, sediments (total sediment and $<63 \mu \mathrm{m}$ fraction) and suspended matter were found at the Botafogo River stations. There was a sharp decrease from the Botafogo River stations to the southern stations, particularly from the Congo River station 3 downstream. The decrease of mercury concentration towards the North was less strong, but distinct. There is a sedimentation area at the head of Itapessoca Island (station 9), where the branches of the Carrapicho River and the Catuama River meet. Strong flood currents and landward winds in the Carrapicho River may transport contaminated material towards station 9 . These factors may explain the more even distribution of mercury in the northern part of the channel, in spite of the decreasing distance from the Botafogo River. The mercury contamination caused by the chloralkali plant at the Botafogo River had a far-reaching impact as compared to other regions, suggesting a relatively high mobility of the mercury. Other authors reported that mercury contamination caused by chlor-alkali plants was limited to a few kilometers around the factory (Rae and Aston, 1981; Krishnakumar and Pillai, 1990; Lenka et al., 1992). In spite of very strong differences in rainfall during the investigation period, mercury concentrations in oysters and suspended matter did not follow a seasonal pattern. Seasonal ambient changes obviously do not cause seasonal remobilization patterns of mercury (Meyer, 1996).

\section{THE FATE OF MERCURY IN THE SEDIMENTS}

Two types of sediment transects can be distinguished in the Santa Cruz Channel: The first type showed a higher accumulation of total mercury in the nearshore intertidal zone. In contrast, the second type (E. Botafogo River, F. Congo River) contained higher concentrations of total mercury in the subtidal zone. Generally, the distribution of total mercury was correlated 
with grain size distribution and total organic matter. The nearshore mercury accumulation as well as the correlation of mercury with the fine-grained sediment fraction and organic matter generally confirm the role of mangrove areas as sinks for heavy metals (Harbison, 1986; Lacerda et al., 1988; Silva et al., 1990). Several factors enhance mercury accumulation in the intertidal areas: In the shallow nearshore areas, the currents are slow and allow sedimentation of fine-grained material. Organic matter originates mainly from the mangrove detritus, which is accumulated in the vicinity of the mangrove trees and support the accumulation of mercury (Figueres et al., 1985; Langston, 1982; Rae and Aston, 1981; Wallace et al., 1982). In addition, anoxic conditions typically found in mangrove sediments support the immobilization of metals (Carvalho and Lacerda, 1992). In anoxic sulphide-rich sediments mercury can be bound as mercury sulphide (HgS), which is a very stable compound (Förstner and Salomons, 1991). The stronger currents in the subtidal areas of transects A-D and $G$ cause oxidation of organic matter and erosion and resuspension of the fine-grained material and do not provide favorable conditions for mercury accumulation.

In contrast to transects $A-D$ and $G$, a different mercury distribution pattern was found for transects $\mathrm{E}$ (Botafogo River) and $\mathrm{F}$ (Congo River), where higher mercury concentrations were determined for the subtidal zones as compared to the intertidal zones. These transects are located in sections with moderate or slow currents, where the subtidal area is not much affected by erosion. Their contrasting mercury distribution patterns cannot be explained by the distribution of fine-grained material, as the mercury distribution in the fine fraction shows the same distribution pattern as the distribution of mercury in the total sediment. Furthermore, total organic matter in these transects is more evenly distributed and not concentrated in the subtidal or intertidal areas. Thus, total organic matter does not determine the observed mercury distribution. These findings suggest losses of mercury in the intertidal areas, which are not caused by erosion processes. Remobilization of metals from sediments can be caused by various parameters such as changing $\mathrm{pH}$ - and redox-conditions (Gambrell et al., 1980; Harbison, 1986) caused e.g. by bioturbation or tidal oxidation (Förstner and Salomons, 1991).

Species transformation (methylation and reduction to $\mathrm{Hg}^{\circ}$ ) mainly in sediments, is the fundamental process controlling the turnover of mercury (Brinckmann and Olson, 1988; Jensen and Jernelöv, 1972). Wallschläger et al. (1995) stressed that mercury remobilization occurs not only into the water column, but also into the air. Transformation to volatile mercury species can result in enormous releases of mercury into the water column and the air: In the Elbe River Wilken et al. (1992) found a transformation rate of $10 \%$ per hour. Such transformation processes can also lead to elevated levels of atmospheric mercury (FAO, 1985). Although these processes may also occur under abiotic conditions (particularly mercury reduction, Allard and Arsenie, 1991; Filip,1986), they are usually the result of microbial activity (Brinckmann and Olson, 1988; Hintelmann and Wilkenm 1994; Jensen and Jernelöv, 1972;). Fine-grained organic-rich sediments in particular are biologically and chemically active (Förstner and 
Salomons, 1991). Especially intertidal flats may act as secondary sources of metals because of this "biological pumping" (Morris et al., 1982). Hence, intertidal mangrovial sediments provide suitable conditions for the transformation of mercury to methylated or elemental species, which might be lost to water or air. A considerable part of the transformed mercury is probably lost to the air due to volatilization. Mangrovial sediments may produce considerable amounts of highly volatile mercury species by bacterial transformation of monomethylmercury into dimethylmercury and elemental mercury (Parlar and Angerhöfer, 1991). Based on the conservative assumption that only $0.5 \%$ of the total mercury (volatile or soluble species) is lost from the sediment into the air or water column within ten days, the annual loss of mercury from the sediment would amount to ca. $160 \mathrm{~kg}$ per ton $(=16 \%)$ of total mercury in the Santa Cruz Channel. This calculation agrees well with the losses (12\%) calculated by Craig and Moreton (1984). This rough estimation emphasizes the significance of this pathway. Although a loss of mercury from the intertidal sediments could only be determined for the two "more typical mangrovial" transects, it is probably a process that can generally occur in the intertidal zones. In the transects with strong currents in the subtidal zones, however, this process could not be detected due to the dominant influence of grain size and erosion.

\section{MERCURY IN SUSPENDED MATTER}

In aquatic systems mercury has a very strong affinity to bind on particles, thus the distribution of mercury in an aquatic ecosystem is determined by suspended matter (Cossa and Noel, 1987; Frenet,1981; Rae and Aston, 1982). According to Cossa and Martin (1991) the main portion of mercury in the water will remain particle-bound. Due to high variability of mercury in suspended matter, the export data through the Exit North can only be regarded as very rough estimates. However, the range of the export calculated for the Exit North is relatively narrow, although the two collections were performed under different seasonal conditions. While no distinct seasonal pattern was observed for the concentration of suspended matter as did Medeiros (1991), a slither higher export of mercury was observed during the dry season relative to that during the rainy season (Fig. 6). In both seasons, export of mercury occurred but was obviously small.

\section{CONCLUSIONS}

Mercury in the sediments of the Santa Cruz Channel is accumulated in the intertidal areas. These areas function as secondary sources. Mercury is remobilized into water or air. Export of mercury through the exits is small. This means that remobilized mercury either cycles in the system or is released into the air. Both processes present a considerable risk for aquatic organisms and humans exposed to the mercury. 


\section{ACKNOWLEDGEMENTS}

We would like to thank Dr. Werner Ekau, the German project leader, and Dr. Sílvio Macêdo, the responsible Brazilian counterpart, for the good cooperation during our studies. We are grateful to Dr. Christian von Dorrien, who was in charge of local logistics, and we appreciate the assistance of Isaac Cristiano de Freitas during many difficult collections in the channel. Mercury analyses were carried out at the Alfred Wegener Institute for Polar and Marine Research in Bremerhaven with special support from Dr. Gerhard Kattner and Dr. Michael Kriews, and at the University of Oldenburg with help from Dr. Jürgen Ritterhoff. This study was funded by the German Federal Minister for Education, Science, Research and Technology (project 0339607A) and by the Senator for Education, Science, Art and Sports in Bremen.

\section{REFERENCES}

Allard, B.; Arsenie, I. (1991), Abiotic reduction of mercury by humic substances in aquatic systems - an important process for the mercury cycle. Water Air Soil Pollution Journal, Vol. 56, pp. 457-464.

Aston, S.R.; Rae, J.E. (1982), An evaluation of the historical response of mercury contamination in estuarine sediments to chlor-alkali effluent treatment. Environment International, Vol. 7, pp.331-336.

Barcellos, C.; Pedlowski, M.A.; Rezende, C.E.; Pfeiffer, W.C., Lacerda, L.D. (1991), Sources and sinks of lead in Sepetiba Bay. In: Proceedings of the International Conference on Heavy Metals in the Environment. CEP Consultants, Edinburgh, Vol. 1, pp.535-538.

Bernhard, M. (1988), Mercury in the Mediterranean. Regional Seas Reports and Studies No. 98, UNEP, $141 \mathrm{p}$.

Blum, J.E.; Bartha, R. (1980), Effect of salinity on methylation of mercury. Bulletin of Environmental Contamination and Toxicology, Vol. 25, pp. 404-408.

Brinckman, F.E.; Olson, G.J. (1988), Global biomethylation of the elements. Its role in the biosphere translated to new organometallic chemistry and biotechnology. In: CRAIG, P.J.; Glockling, F. (eds): The Biological Alkylation of Heavy Metals. The Royal Society of Chemistry. Spec. publ. No. 56, London, pp. 168-196.

Brock, V. (1992), Effects of mercury on the biosynthesis of porphyrins in bivalve molluscs (Cerastoderma edule (L.) and C. lamarcki (Reeve)). Journal of Experimental Marine Biology and Ecology, Vol. 164, pp. 17-29

Brown, B.E. (1998), Fate of metals on biota and biological interactions in the tropical coastal zone. In: Seelinger, U.; Lacerda, L.D.; Patchineelam, S.R.: Metals in Coastal Environments of Latin America. Springer Verlag, Berlin, Heidelberg, pp. 109-121.

Carvalho, C.E.V.; Lacerda, L.D. (1992), Heavy metals in the Guanabara Bay biota: why such low concentrations? Ciência e Cultura, Vol. 44, pp. 184-186.

CETESB (Companhia de Tecnologia de Saneamento Ambiental) (1981), Estudo de Mercúrio nas águas e estuário do Rio Botafogo - Pernambuco - 1981. Fase I - Estudo preliminar. São 
Paulo, 39 p.

CETESB (Companhia de Tecnologia de Saneamento Ambiental) (1984), Levantamento de Cargas e Dispersão de Mercúrio do Rio Botafogo, em Recife - PE, São Paulo, 109 p.

Compeau, G.; Bartha, R. (1983), Effects of sea salt anions on the formation and stability of methylmercury. Bulletin of Environmental Contamination and Toxicology. Vol. 31, pp. 486493.

Cossa, D.; Martin, J.M. (1991), Mercury in the Rhone delta and adjacent marine areas. Marine Chemistry, Vol. 36, pp. 291-302.

Cossa, D.; Noel, J. (1987), Concentrations of mercury in near shore surface waters on the Bay of Biscay and in the Gironde Estuary. Marine Chemistry, Vol. 20, pp. 389-396.

Craig, P.J.; Moreton, P.A. (1984), The role of sulphide in the formation of dimethyl mercury in river and estuary sediments. Marine Pollution Bulletin, Vol. 15, pp. 406-407.

FAO. (1985), Report of the FAO/UNEP/WHO/IOC/IAEA Meeting on the Biogeochemical Cycle of Mercury in the Mediterranean, Siena, Italy, 27-31 August 1984. FAO Fisheries Report No. 325, Rome, $17 \mathrm{p}$.

Figueres, G.; Martin, J.M.; Meybeck, M.; Seyler, P. (1985), A comparative study of mercury contamination in the Tagus Estuary (Portugal) and major French estuaries (Gironde, Loire, Rhone). Estuarine Coastal and Shelf Science, Vol. 20, pp. 183-203.

Filip, Z. (1986), Mikroorganismen und Quecksilber - eine Übersicht. Forum Städte-Hygiene, Vol. 37, pp. 243-246.

Florence, T.M. (1982), The speciation of trace metals in waters. Talanta, Vol. 29, pp. 345-364.

Förstner, U.; Salomons, W. (1991), Mobilization of metals from sediments. In: MERIAN, E. (ed.): Metals and Their Compounds in the Environment. Occurrence, Analysis, and Biological Relevance. VCH, Weinheim, pp. 379-398.

Frenet, M. (1981), The distribution of mercury, cadmium and lead between water and suspended matter in the Loire Estuary as a function of the hydrological regime. Water Research, Vol. 15, pp. 1343-1350.

Gambrell, R.P.; Khalid, R.A.; Patrick, W.H. (1980), Chemical availability of mercury, lead, and zinc in Mobile Bay sediment suspensions as affected by $\mathrm{pH}$ and oxidation-reduction conditions. Environmental Science \& Technology, Vol. 14, pp. 431-436.

GESAMP (1988), IMO/FAO/UNESCO/WMO/WHO/IAEA/UN/UNEP Joint Group of Experts and the Scientific Aspects of marine Pollution) Arsenic, mercury and selenium in the marine environment. Regional Seas Report and Studies No. 92, UNEP, 172 p.

Gomez, E.D. (1988), Overview of environmental problems in the East Asian Seas region. Ambio, Vol. 17, pp. 166-169.

Harbison, P. (1986), Mangrove muds - A sink and source for trace metals. Marine Pollution Bulletin, Vol. 17, pp. 246-250. 1986.

Hatch, W.R.; Ott, W.L. (1968), Determination of sub-microgram quantities of mercury by 
atomic adsorption spectrophotometry. Analitical Chemistry, Vol. 40, pp. 1085-1087.

Hintelmann, H.; Wilken, R.D. (1994), Methylquecksilberverbindungen - Belastungsschwerpunkte im Längsschnitt der Elbe. Vom Wasser, Vol. 82, pp.163-173.

IUCN (Int. Union Conservation of nature resources) (1983), Global Status of Mangrove Ecosystems. Gland, Switzerland, 88 p.

Jensen, S.; Jernelöv, A. (1972), Behaviour of mercury in the environment. In: Mercury Contamination in Man and his Environment. Technical Report Series 137, International Atomic Energy Agency, Wien, p. 43-47.

Khan, A.T.; Weis, J.S. (1987), Effect of methylmercury on egg and juvenile viability in two populations of killifish Fundulus heteroclitus. Environmental Research, Vol. 44, pp. 272278.

Kjerfve, B.; Medeiros, C. (1989), Current vanes for measuring tidal currents in estuaries. Estuarine Coastal and Shelf Science, Vol. 28, pp. 87-93.

Krishnakumar; P.K.; Pillai, V.K. (1990), Mercury near a caustic soda plant at Karwar, India. Marine Pollution Bulletin, Vol. 21, pp. 304-307.

Kudo, A.; Miyahara, S. (1988), Effect of decontamination project at Minamata Bay, Japan. Dramatic decrease of mercury dispersed into Yatsushiro Sea. (editorial comment). Ecotoxicology and Environmental Safety, Vol. 15, pp. 339-343.

Lacerda, L.D. (1993), Mangroves of Latin America and the Caribbean: An overview. Proceedings of a Workshop on Conservation and Sustainable Utilization of Mangrove Forests in Latin America and Africa Regions. Mangrove Ecosystems Proc., Dakar, 2, Dakar, p. 26-31.

Lacerda, L.D.; Rezende, C.E.; Aragon, G.T.; Ovalle, A.R.C. (1991), Iron and chromium transport and accumulation in a mangrove ecosystem. Water, Air and Soil Pollution, Vol. 57-58, pp. 513-520.

Lacerda, L.D.; Souza, C.M.M.; Pestana, M.H.D. 1988. Geochemical distribution of Cd, $\mathrm{Cu}, \mathrm{Cr}$ and $\mathrm{Pb}$ in sediments of estuarine areas along the Southeastern Brazilian coast. In:

Langston, W.J. (1982), The distribution of mercury in British estuarine sediments and its availability to deposit-feeding bivalves. Journal of Marine Biological Association, UK, Vol. 62, pp. 667-684.

Lenka, M.; Panda, K.K.; Panda, B.B. (1992), Monitoring and assessment of mercury pollution in the vicinity of a chloralkali plant. IV. Bioconcentration of mercury in situ aquatic and terrestrial plants at Ganjam, India. Archives of Environmental Contamination and Toxicology, Vol. 22, pp. 195-202

Loring, D.H.; Rantala, R.T.T. (1992), Manual for the geochemical analyses of marine sediments and suspended particulate matter. Earth-Science Reviews, Vol. 2, pp. 235-283.

Mackey, A.P.; Hodgkinson, M.; Nardella, R. (1992), Nutrient levels and heavy metals in mangrove sediments from the Brisbane River, Australia. Marine Pollution Bulletin, Vol. 24, pp. 418-420. 
Maddock, J.E.L.; Motta, A.L.G. (1982), Measurement of estuarine heavy metal pollution in the state of Rio de Janeiro (Brazil) by analysis of mangrove bushes. Atlantica, Vol. 5, pp. 75.

Martin, M.; Osborn, K.E.; Billig, P.; Glickstein, N. (1981), Toxicities of ten metals to Crassostrea gigas and Mytilus edulis embryos and Cancer magister larvae. Marine Pollution Bulletin, Vol. 12, pp. 305-308.

Medeiros, C. (1991), Circulation and Mixing in the Itamaracá Estuarine System, Brazil. Ph.D. thesis, Univ. South Carolina, USA, $131 \mathrm{p}$.

Meyer, U. (1996), On the fate of mercury in the northeastern Brazilian mangrove system Canal de Santa Cruz, Pernambuco. ZMT-Contributions 3, Center for Tropical Marine Ecology, Bremen, Germany, 105 p. 1996.

Miskimmin, B.M. (1991), Effect of natural levels of dissolved organic carbon (DOC) on methyl mercury formation and sediment-water partitioning. Bulletin of Environmental Contamination and Toxicology, Vol. 47, pp. 743-750.

Morris, A.W.; Bale, A.J.; Howland, R.J.M. (1982), The dynamics of estuarine manganese cycling. Estuarine, Coastal and Marine Science, Vol. 13, pp. 175-192.

Müller, L.; Kaiser, B.; Ohnesorge, F.K. (1991), Vorkommen und Bedeutung von Quecksilber. In: Aurand, K.; Hässelbarth, U.; Lange-Asschenfeldt, H.; Steuer, W. (ed.): Die TrinkwasserVerordung - Einführung und Erlüuterungen für Wasserversorgungsunternehmen und Überwachungsbehörden. Erich Schmidt, Berlin, pp. 259-268.

Nascimento, I.A. (1982), Inhibition of embryonic development of the mangrove oyster (Crassostrea rhizophorae) by heavy metals. Atlântica, Vol. 5, pp. 84.

Parlar, H.; Angerhöfer, D. (1991). Chemische Ökotoxikologie. Springer Verlag, Berlin, Heidelberg, $384 \mathrm{p}$.

Pfeiffer, W.C.; Fiszman, M.; Lacerda, L. (1988). Heavy metal surveys in Brazilian coastal environments. In: Seelinger, U.; LAcerda, L.D.; Patchineelam, S.R. (eds.): Metals in Coastal Environments of Latin America. Springer Verlag, Berlin, Heidelberg, p. 3-8.

Queiroz, A.F.S.; Mosser, C.; Santos, A.L.F. (1993), Heavy metals concentration in sediments of mangrove swamps of the Todos os Santos Bay - Bahia - Brazil. In: Abrão, J.J. Seelinger, U.; Lacerda, L.D.; Patchineelam, S.R. (eds.): Metals in Coastal Environments of Latin America. Springer Verlag, Berlin, Heidelberg, p. 86-99.

Rae, J.E.; Aston, S.R. (1982), The role of suspended solids in the estuarine geochemistry of mercury. Water Research, Vol. 16, pp. 649-654.

Rae, J.E.; Aston, S.R. (1981), Mercury in coastal and estuarine sediments of the northeastern Irish Sea. Marine Pollution Bulletin, Vol. 12, pp. 367-371.

Ramlal, P.S.; Rudd, J.W.M.; Furutani, A.; Xun, L. (1985), The effect of pH on methyl mercury production and decomposition in lake sediments. Canadian Journal of Fisheries and Aquatic Science, Vol. 42, pp. 685-692.

Salomons, W.; Förstner, U. (1984), Metals in the Hydrocycle. Springer-Verlag, Berlin, 349 p.

Silva, C.A.R.; Lacerda, L.D.; Rezende, C.E. (1990), Metal reservoir in a red mangrove forest. 
Biotropica, Vol. 22, pp. 339-345.

Von Burg, R.; Greenwood, M.R. (1991), Mercury. In: Merian, E. (ed.): Metals and Their Compounds in the Environment. Occurrence, Analysis, and Biological Relevance. VCH, Weinheim, pp. 1045-1088.

Wallace, G.T., JR.; Seibert, D.L.; Holzknecht, S.M.; Thomas, W.H. (1982), The biogeochemical fate and toxicity of mercury in controlled experimental ecosystems. Estuarine Coastal and Shelf Science, Vol. 15, pp. 151-182.

Wallschläger, D.; Desai, M.V.M.; SPengler, M.; Wilken, R.D. (1995), Mercury in contaminated sediments and floodplains of the River Elbe - assessment of major species and mobilization behaviour. In: Wilken, R.D.; Förstner, U.; Knöchel, A. (eds.): Proceedings of the International Conference on Heavy Metals in the Environment, CEP Consultants, Hamburg, Vol. 2, pp. 52-56.

Wasserman, J.C.; Silva Filho, E.V. (eds.) (1993), Proceedings of the International Symposium on Perspectives for Environmental Geochemistry in Tropical Countries. Niterói, Brazil, 28.11.-3.12.93. Universidade Federal Fluminense, Niterói, pp. 123-126.

WHO (1976), Mercury. Environmental Health Criteria 1. WHO World Health Organization, Geneva, 132 p.

Wilken, R.D.; Hintelmann, H.; Ebinghaus, R. (1992), Biologische Quecksilberumsetzungen in der Elbe. Vom Wasser, Vol. 74, pp. 383-392.

Woodroffe, C.D. (1985), Studies of a mangrove basin, Tuff Crater, New Zealand: II. Comparison of volumetric and velocity-area methods of estimating tidal flux. Estuarine, Coastal and Shelf Science, Vol. 20, pp. 431-445.

Wright, D.R.; Hamilton, R.D. (1982), Release of methyl mercury from sediments: Effects of mercury concentration, low temperature, and nutrient addition. Canadian Journl of Fisheries and Aquatic Science, Vol. 39, pp.1459-1466. 